ВІСНИК

ОДЕСЬКОГО НАЦІОНАЛЬНОГО

МОРСЬКОГО УНІВЕРСИТЕТУ

№ 1 (64), 2021
HERALD

OF THE ODESSA NATIONAL

MARITIME UNIVERSITY

№ 1 (64), 2021

УДК 656.073.7:656.613.1

DOI 10.47049/2226-1893-2021-1-112-123

\title{
МЕТОДИКА УЗГОДЖЕНОГО УПРАВЛІННЯ ПІДПРИСМСТВАМИ НА БАЗІ ТРАНСПОРТНОГО ВУЗЛА
}

\author{
А.O. Мурад'ян \\ к.т.н., доцент кафедри «Експлуатація портів і технологія вантажних робіт» \\ Одеський національний морський університет, Украӥна, Одеса
}

Анотація. Виділена задача, а саме управління взаємодіючими підприємствами у транспортних вузлах має більш ніж вікову історію, але вона у загальній постановиі залишається до теперішнього часу недостатньо вивченою. Наявні результати досліджень можуть лише частково використовуватися для їі вирішення внаслідок їх фрагментарності і неповної відповідності ринковій філософії управління реальним транспортним виробництвом, включаючи етапи перевезення і перевалювання вантажів.

Спроба усунути ињю «білу пляму» у транспортної науці, а саме розробити методику управління взаємодіючими підприємствами у транспортних вузлах здійснюється у даній статті.

Виконано дослідження комплексу питань, що пов'язано з постановкою та аналізом проблеми забезпечення узгодженого управління взаємодіючими транспортними системами при здійсненні прочесів перевезення та перевалювання вантажів. На сучасному етапі для розв'язання иієї проблеми було використано теоретіко-методичну базу, що грунтується на складанні принципів традиџійної теорії управління, соціального управління, маркетингу взаємодї та теорії ігор.

Визначено структуру механізму забезпечення узгодженого управління з виділенням етапів досягнення та реалізачії виробляємих рішень.

Ключові слова: транспортна система, взаємодія, співпрачя, конкуренція, узгодження управління, досягнення та реалізація узгодженого.

УДК 656.073.7:656.613.1

DOI 10.47049/2226-1893-2021-1-112-123

\section{МЕТОДИКА СОГЛАСОВАННОГО УПРАВЛЕНИЯ ПРЕДПРИЯТИЯМИ НА БАЗЕ ТРАНСПОРТНОГО УЗЛА}

А.О. Мурадьян

к.т.н., доцент кафедры «Эксплуатация портов и технология грузовых работ»

Одесский национальный морской университет, Украина, Одесса

(C) Мурадьян A.O., 2021 
ВІСНИК

ОДЕСЬКОГО НАЦІОНАЛЬНОГО

МОРСЬКОГО УНІВЕРСИТЕТУ № 1 (64), 2021
HERALD

OF THE ODESSA NATIONAL

MARITIME UNIVERSITY № 1 (64), 2021

Аннотация. Выделенная задача, а именно управление взаимодействующими предприятиями в транспортных узлах имеет более чем вековую историю, но она в общей постановке остается до настоящего времени недостаточно изученной. Имеюшчеся результаты исследований могут лишь частично использоваться для ее решения вследствие их фрагментарности и неполного соответствия рыночной философии управления реальным транспортным производством, включая этапь перевозки и переваливания грузов.

Попьтка устранить это «белое пятно» в транспортной науке, а именно разработать методику управления взаимодействуюшими предприятиями в транспортных узлах осуществляется в данной статье.

Выполнено исследование комплекса вопросов, что связано с постановкой и анализом проблемы обеспечения согласованного управления взаимодействующими транспортными системами при осуществлении прочессов перевозки и переваливания грузов. На современном этапе для решения этой проблемы была использована теоретико-методическая база, основанная на составлении принципов традиционной теории управления, социального управления, маркетинга взаимодействия и теории uгp.

Определена структура механизма обеспечения согласованного управления с выделением этапов достижения и реализации производимых решений.

Ключевые слова: транспортная система, взаимодействие, сотрудничество, конкуренция, согласование управления, достижение и реализаџия согласованного.

UDC 641. 546.45

DOI 10.47049/2226-1893-2021-1-112-123

\title{
METHODOLOGY OF HARMONIZED MANAGEMENT OF ENTERPRISES ON THE BASIS OF TRANSPORT HUB
}

\author{
A.O. Muradyan \\ $\mathrm{PhD}$, Associate Professor \\ of the Department «Port Operation and Cargo Handling» \\ Odessa National Maritime University, Ukraine, Odessa
}

\begin{abstract}
The selected task, namely the management of interacting enterprises in transport hubs has more than a century of history, but it in the general setting remains to this day insufficiently studied. The available research results can only be partially used to address it due to their fragmentary nature and incomplete compliance with the market philosophy of real transport production management, including the stages of transportation and transshipment of goods. An attempt to eliminate this "white spot» in transport science, namely to develop a methodology for managing interacting enterprises in transport hubs is carried out in this article. A study of a set of
\end{abstract}


issues related to the formulation and analysis of the problem of ensuring the coordinated management of interacting transport systems in the implementation of the processes of transportation and transshipment of goods.

At the present stage, a theoretical and methodological basis has been used to solve this problem, based on the principles of traditional management theory, social management, interaction marketing and game theory.

The structure of the mechanism of providing the coordinated management with allocation of stages of achievement and realization of the made decisions is defined.

Keywords: transport system, interaction, cooperation, competition, coordination of management, achievement and implementation of coordinated management.

Вступ. Поглиблення на рубежі XX-XXI століть інтергації сфер виробництва, обігу та споживання призвело до утвердження єдиного народногосподарського комплекса «виробництво-транспорт-розподілзбут», що послужило імпульсом до актуалізації концепцій доставки вантажів «від дверей до дверей» і «точно у строк» 3 використанням юнімодальних (одновидових) та мультимодальних (багатовидових) транспортних систем. В останьому випадку на перший план висувається проблема досягнення узгодженого функціонування взаємодіючих транспортних систем (ВТС) - суміжних залізниць, суміжних ланок транспортних коридорів, підприємств транспортно-логістичних систем доставки вантажів. Ця тенденція, у свою чергу, визначила необхідність розв'язання адекватної комплексної задачі шляхом розробки механізму забезпечення узгодженого управління ВТС як умови і засобу скорочення витрат на доставку вантажів за принципом «від дверей до дверей», включаючи видатки транспортних підприємств.

Виділена задача має більш ніж вікову історію, але вона у загальній постановці - для класу систем вида ВТС - залишається до теперішнього часу недостатньо вивченою. Наявні результати досліджень можуть лише частково використовуватися для іï вирішення внаслідок їх фрагментарності і неповної відповідності ринковій філософії управління реальним транспортним виробництвом, включаючи етапи перевезення і перевалювання вантажів.

Спроба усунути цю «білу пляму» у транспортній науці здійснюється у даній статті.

Постановка проблеми. Початковий етап створення механізму забезпечення узгодженого управління ВТС логічно пов'язати з обгрунтуванням теоретико-методичної бази дослідження відповідної цьому проекту задачі. Очевидно, що така наукова база повинна бути адекватною, 3 одного боку, організаційно-економічній суті означеної задачі, а з іншого боку, - сучасним уявленням про організацію управління транспортними процесами. 
3 аналізу основних умов вказаної задачі слідує, що при управлінні ВТС принципово важливі серед них полягають у логіці:

- об'єднання ВТС у віртуальну систему;

- зіставлення інтересів і запобігання конфронтації ВТС;

- забезпечення дотримання однакових прав для усіх ВТС; питань

- усунення протистояння ВТС при пошуку розв'язання спірних

Покажемо, що реалізацію такого роду умов необхідно здійснювати у рамках нової парадигми ділової поведінки суб'єктів підприємницької діяльності, яка грунтується на методології традиційної теорії управління в поєднанні з ідеями соціального управління, маркетингу взаємодії і теорії ігор. Охарактеризуємо коротко ці положення у контексті перелічених теорій для того, щоб об'єднати їх ідеї, які є складовими концепції забезпечення узгодженого управління ВТС.

Аналіз останніх досліджень і публікацій. Попередньо відзначимо, що збиральна назва «взаємодіючі транспортні системи» (ВТC) у транспортній науці раніше не фігурувала, що пояснює відсутність публікацій $з$ використанням такого поняття. В той же час по окремим видам ВТС існує досить численна бібліографія, що містить публікації про теоретичні дослідження, які проводилися в галузі комплексних транспортних проблем, інтеграції управління різними видами транспорту і системами сполучених транспортних підприємств, створення механізмів управління транспортними вузлами, транспортно-технологічними та транспортнологістичними системами, що знайшло відображення у багатьох публікаціях, зокрема, в роботах [1-3], виконаних на протязі останнього часу.

Iз аналізу згаданих публікацій легко вбачається їх загальна особливість, яка полягає у відсутності конкретики при обговоренні теоретичної складової механізму реалізації управління ВТС. Із цього приводу в кращому випадку декларується ідея необхідності опрацювання вказаного механізму, але без вказівки на спосіб вирішення такого завдання.

Цей висновок підсилюється також результатами аналізу методичного аспекту узгодження управління ВТС. Підкреслимо, що лише на рубежі XX-XXI століть у цьому напрямку був виконаний ряд досліджень, присвячених, із одного боку, критичному аналізу висунутих раніше пропозицій щодо використання в якості механізму управління ВТС економіко-математичних моделей i, з іншого боку, пошуку нових можливостей для забезпечення узгодженого управління ВТС. При цьому було встановлено, що в означений період намітилася тенденція використання при розробці характеризуємої задачі поряд із підходами традиційної теорії управління, також можливості висунутих західноєвропейськими вченими концепцій організації управління на транспорті, які засновані на положеннях теорії взаємодіючих систем, морфологічного та когнітивного моделювання, штучного інтелекту, системного програмування і мультиагентної оптимізації [3-6]. Протее, ці ініціативи не призвели до ство- 
рення методів управління ВТС, що враховують умови роботи транспорту в ринковому середовищі.

Початок XXI століття ознаменувався також наростанням суперництва двох парадигм управління - традиційної теорії управління, об'єктами якої є людино-машинні системи, і новою наукою ділової поведінки, яка орієнтується на управлінні організаційно-економічними системами і розвивається на базі соціального управління, маркетингу взаємодії і теорії ігор. Ця тенденція проявилася і в дослідницькій діяльності на транспорті, у тому числі щодо комплексних транспортних проблем, включаючи і управління ВТС.

Межевою, в певному сенсі, можна вважати роботу [8], в якій зроблена спроба поєднати раціональні ідеї традиційного і нового підходів до організації управління ВТС. Перший із зазначених напрямків - традиційний - представлено з орієнтацією на вибір у якості прийнятного методичного засобу для побудови механізму управління транспортними вузлами морфологічного та когнітивного моделювання в поєднанні зі сценарним підходом до планування діяльності вузла.

Другий і більш цінний напрямок - ринковий - відображено в [7] у формі обгрунтування проблеми узгодження інтересів суб'єктів транспортних вузлів у ході організації та здійсненні процесів перевалювання вантажів. Цей напрямок виконаний у поняттях теорії оцінки впливу зворотнього зв'язку в механізмі управління на функціонування керованого об'єкта. При цьому всі зазначені ідеї розглянуті, як прийнято говорити, лише в порядку постановки питання.

Протягом останнього п'ятнадцятиріччя вийшли публікації, у яких піднімаються питання про організацію взаємодії підприємств суміжних видів транспорту на довгостроковому і короткостроковому інтервалах управління [8-12]. У роботах першого напряму увага акцентується на використанні ймовірнісних методів і методів імітаційного моделювання. У такому ж ключі взаємодія транспортних підприємств трактується при формуванні транспортно-логістичних ланцюгів у мультимодальних перевезеннях, функціонування яких (ланцюгів) розглядається в довгостроковій перспективі. При цьому у всіх зазначених працях питання про розробку механізма узгодженого управління суміжними транспортними системами безпосередньо не піднімається. У той же час у статтях [10-12] покладено початок дослідженням функціонування вказаних систем із використанням теорій динамічної оптимізації і управління запасами, що в принципі відповідає потребам організації управління взаємодіючими транспортними системами на короткострокових інтервалах.

Узагальнення вищевикладеного дозволяє зробити висновок, що при спільному розгляді охарактеризованих ідей і концепцій управління транспортними системами стає очевидним недолік у сучасній науковій літературі конструктивних пропозицій, спрямованих на розробку підходу до узгодженого управління взаємодіючими системами. 
Формулювання цілей статті. Ціллю даного дослідження є розробка концептуальних основ здійснення узгодженого управління ВТС, що забезпечує у кінцевому рахунку скорочення витрат, по-перше, транспортних підприємств на реалізацію перевезення і перевалювання вантажів i, по-друге, транспортної клієнтури щодо доставки вантажів.

Для досягнення цієї цілі поставлені наступні задачі:

- на основі результатів аналізу сучасного стану управління визначити вимоги до механізму забезпечення узгодженого управління ВТС;

- показати, що розробку вказаного механізму необхідно будувати у відповідності 3 нормами сучасної ділової поведінки контактуючих транспортних систем;

- охарактеризувати теоретико-методичну базу для розробки механізму забезпечення узгодженого управління ВТС;

- синтезувати структуру механізму забезпечення узгодженого управління ВТС.

Виклад основного матеріалу. Дотримуючись наміченого підходу, зазначимо, що в традиційній теорії управління основоположний принцип забезпечення узгодженого управління комплексами контактуючих систем грунтується на поняттях координації та взаємодії. При цьому під координацією розуміється управління, яке здійснюється 3 метою узгодження процесів в різних елементах (підсистемах) об'єкта управління, або забезпечення узгодженості елементів керованого об'єкта. Поняття взаємодії пов'язують із встановленням взаємного зв'язку контактуючих суб'єктів, їх взаємної обумовленості, а також з підтримкою і розвитком ділових взаємовідносин.

Наведені положення означають, що координація і взаємодія в управлінні органічно поєднуються як взаємозалежні, взаємообумовлені і об'єктивно нероздільні категорії. При цьому координація забезпечує цілеспрямованість керованого процесу, яка виробляється завдяки взаємодії суб'єктів управління, спільно реалізуючих зазначений процес.

3 останнього твердження випливає логічний висновок про пріоритетну роль взаємодії у здійсненні цілеспрямованої поведінки складних систем будь-якої природи. Дійсно, взаємодія як процес інтеграції спрямованого функціонування контактуючих суб'єктів завжди пов'язується 3 досягненням певного результату, до якого вони можуть прагнути як до спільної мети в альянсі, або як до особистих цілей незалежно. В обох випадках орієнтація суб'єктів на результат передбачає цілеспрямованість спільної діяльності як підсумок реалізації їх взаємодії.

3 цієї причини в традиційній теорії управління поняття взаємодії досі асоціюється тільки з конструктивним ефектом у досягненні узгодженості в управлінні контактуючими суб'єктами. 
Проте в реальному світі і особливо в ринковому середовищі взаємодія суб'єктів може здійснюватися під знаком не тільки їх сприяння, але і протидії один одному, а також без взаємного впливу, що відображено на схемі, показаній на рисунку.

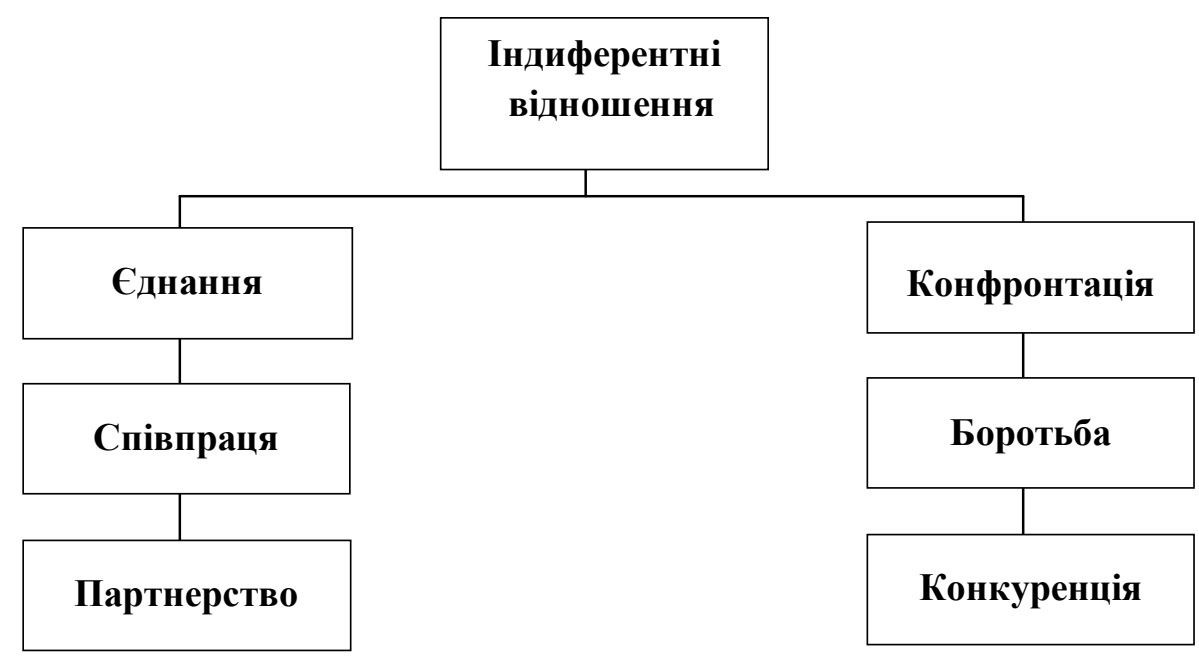

Рисунок. Схема реалізаиї процесу взаємодії контактуючих суб'єктів

Підкреслимо, що в економічній теорії конкуренція в єдності зі співпрацею розглядаються як системні параметри сучасної системи бізнесу, a їх конфронтаційний взаємозв'язок визначається як парадокс системності бізнесу.

Існування економічних інститутів співпраці i конкуренції та полярність їх «векторів» $є$ реальною об'єктивністю в будь-якому середовищі людського буття. Тим самим обумовлюється необхідність забезпечення в управлінні складними системами і процесами гармонійного поєднання зазначених інститутів, що досягається шляхом реалізації їх атрибутів прояви як умови вирішення (усунення) протиріч взаємодіючих суб'єктів. Такий підхід розвивається у сучасній теорії соціального управління, де показано, що згаданими атрибутами $\epsilon$ толерантність, діалог, здатність до досягнення компромісу і консенсусу, єдність яких є умовою встановлення згоди контактуючих суб'єктів на основі колективно-групових цінностей, включаючи групову солідарність.

3 вищевикладеного випливає, що концепція узгодження управління комплексами взаємодіючих систем повинна зв'язуватися з орієнтацією на пошук такого узгодженого (колективно прийнятого) рішення, яке б забезпечувало у повній мірі інтереси всіх суб'єктів розглядаємої комплексної системи. На мові економічної теорії ця умова означає, що контактуючі суб'єкти повинні пристосовуватись до змін в їх чистій вигоді. 
Цей принцип розвивається також в інтенсивно прогресуючій на сучасному етапі теорії маркетингу взаємодії або партнерських відносин, методологічна суть якого досить повно передається наступним визначенням: маркетинг взаємодії - це неперервний процес визначення і створення нових цінностей продавцями спільно 3 покупцями, спільного одержання і розподілу вигоди (зиску) від цієї діяльності між усіма учасниками взаємодії.

Серцевинна ідея маркетингу взаємодії базується на принципах рівноправності контактуючих суб'єктів і неприпустимості максимізації ступеня задоволення інтересів одних з них за рахунок утиснення інтересів інших при розподілі спільно видобутого прибутку (вигоди). За таких умов головною задачею управління комплексними системами стає, як і в теорії соціального управління, примирення суперечливих інтересів взаємодіючих суб'єктів шляхом виділення так званих «зон толерантності» (формально - зон оптимальності за Парето), вихід за межі яких породжує конфлікти інтересів суб'єктів в межах їх об'єднань з усіма витікаючими негативними наслідками.

Отже, взаємодіючі суб'єкти виступають одночасно в якості ділових партнерів і конкурентів, активність яких пов'язується в кінцевому рахунку 3 орієнтацією на досягнення кожним із них власної вигоди при вирішенні задач управління процесами, які сумісно організуються і здійснюються. Наявність конкурентної складової у відносинах між контактуючими суб'єктами надає зазначеним задачам конфліктний характер, що дозволяє досліджувати їх з використанням методичного арсеналу теорії ігор. За такої умови взаємодіючі суб'єкти виступають в якості гравців, варіанти їх ділової поведінки - як стратегії, спільно обрані стратегії (загальні рішення) - як результати гри, а досягнення гравцями вигоди - як виграш кожного $з$ них.

Виходячи 3 вищевикладеного, синтез механізму забезпечення узгодженого управління ВТС можливий на основі поєднання складових елементів охарактеризованих вище теорій:

- у традиційній теорії управління категорії координації та взаємодії, що грають визначальну роль у зародженні і реалізації відносин співробітництва і конкуренції у ВТС;

- у теорії соціального управління принципи досягнення та підтримання взаємоприйнятної згоди ВТС як засіб вирішення протиріч шляхом реалізації атрибутів прояви інститутів співробітництва та конкуренції;

- у маркетингу взаємодії принцип забезпечення рівноправності ВТС як умови недопущення конфліктів інтересів;

- у теорії ігор формальний інструментарій для об'єктивного вирішення конфліктних ситуацій в управлінні ВТС. 
Виділені положення дають досить чітке уявлення про принципово важливі грані механізму забезпечення узгодженого управління ВТС і в силу цього можуть трактуватися як його системоутворюючі елементи, повного набору яких, до речі сказати, немає в жодній із згадуваних вище теорій управління.

Виходячи 3 поставлених у даній статті задач дослідження, будемо орієнтуватися при формуванні характеризуємого механізму на розроблення методичного забезпечення як досягнення, так і реалізації узгодженого управління ВТС. У першому випадку питання необхідно розглядати в постановці, що передбачає узгодження параметрів керованого процесу, які приймаються на встановлений термін дії, а в другому випадку на забезпечення дотримання узгоджених параметрів на етапі оперативного управління роботою ВТС.

Висновки. У результаті здійснюваних досліджень:

- сформульована постановка задачі розроблення механізму забезпечення узгодженого управління ВТС, що дозволило визначити логіку розв'язання цієї задачі;

- показано, що розробку вказаного механізму необхідно орієнтувати на дотримання норм сучасної ділової поведінки контактуючих транспортних систем;

- обгрунтовано теоретико-методичну базу розробки механізму забезпечення узгодженого управління ВТС на основі сполучення принципів традиційної теорії управління, соціального управління, маркетингу взаємодії та теорії ігор;

- сінтезована структура розглядаємого механізму з включенням до неї основоположних елементів згаданих вище теорій, включаючи категорії співробітництва та конкуренції, усунення протиріч, рівноправність суб'єктів взаємодії, вирішення конфліктних ситуацій.

У подальших дослідженнях необхідно зосередитися на методичному аспекті розробки механізму забезпечення узгодженого управління ВТС на етапі досягнення погодженості управління і реалізації узгодженого управління $з$ відображенням умов і вимог, які $€$ актуальними для контактуючих транспортних систем.

\section{ЛIТЕРАТУРА}

1. Морозова И.В. Управление интегрированной логистической цепью поставок на базе концепџии «точно в срок» путем создания временных шлюзов [Текст] / И.В. Морозова, Н.И. Ляшенко // Методи та засоби управління розвитком транспортних систем: 3б. наук. прачь. - 2008. - № 13. - Одеса: OHMY. - C. 5-19. 
ВІСНИК

ОДЕСЬКОГО НАЦІОНАЛЬНОГО

МОРСЬКОГО УНІВЕРСИТЕТУ

№ 1 (64), 2021
HERALD

OF THE ODESSA NATIONAL

MARITIME UNIVERSITY

2. Кириллова Е.В. Организация и управление работой судов в ролкерной транспортно-технологической системе [Текст]: дис. канд. техн. наук: 05.22.01 / Кириллова Елена Викторовна. - Одесса, 2005. - 229 c.

3. Dorigo M. The Ant System: Optimization by a colony of coopereting agents. IEEE Transactions on Systems, Man and Cybernetics [Text] / M. Dorigo, V. Maniezzo, A. Colorni. - Part B. Vol. 26. № 1. - 1996. - P. 1-13.

4. Krishnaiyer K. Ant Algorithms [Text]: review and Future Applications / K. Krishnaiyer, S.H. Cheragh // IERC'02, Industrial Engineering Research Conference, Orlando, USA, may 2002.

5. Ritchey T. Scenario Development and Risk Management using Morphological Field Analysis [Text] / T. Ritchey. Proceedings of the 5th European Conference on Information Systems (Cork: Cork Publishing Company). - Vol. 3. - P. 1053-1059.

6. Zwicky F. Discovery, Invention, Research - Through the Morphological Approach [Text] / F. Zwicky, Toronto, 1969. - The Macmillan Company. - 187 .

7. Сычев А.А. Организачия работы транспортного узла в составе транспортного коридора [Текст]: дис. ... канд. техн. наук / А.А. Сычев. - Ростов-на-Дону: РГУПС, 2009. - 167 c.

8. Rizzoli A.E. A simulation tool for combined/rail/ road transport in intermodal terminals [Text] / A.E. Rizzoli, N. Fornara, L.M. Gambardella // Mathematics and Computers in Simulation. 2002. - Vol. 59. - Issues 1-3. - P. 57-71. DOI: 10.1016/s03784754(01) 00393-7.

9. Белеикий Ю.В. Анализ системы взаимодействия различных видов транспорта на основе формирования транспортнологистических иепей при мультимодальных перевозках [Текст] / Ю.В. Белеикий, Н.В. Мирошникова, А.В. Сергиенко // Вісник Східноукраӥнського наџіонального університету ім. В. Даля. - 2015. - № 1 (218). - С. 210-219.

10. Brandimarte P. Introduction to distribution logistics [Text] / P. Brandimarte, G. Zotteri. - J. Wiley \& Sons, Inc., NY, 2007. $587 \mathrm{p}$.

11. Morozova I.V. Dynamic Optimization Model for Planning of Integrated Logistical System Functioning [Text] / I.V. Morozova, M.Ya. Postan, S.N. Dashkovskiy // Lecture Notes in Logistics, 2014. - P. 291-300. DOI : 10.1007/978-3-642-35966-8-24.

12. Мурад'ян А.О. Методика узгодження параметрів $і$ оптимізаиіі прочесу перевалки вантажів в загальнотранспортних вузлах [Текст] / А.О. Мурад'ян // Вісник Одеського національного морського університету: Зб. наук. праџь. - Одеса: OHMУ, 2014. - Bun. 1 (40). - C. 127-135. 


\section{REFERENCES}

1. Morozova, I.V. Upravlenie integrirovannoi logisticheskoi tsep'yu postavok na baze kontseptsii "tochno $v$ sroK» putem sozdaniya vremennykh shlyuzov [Text] / I.V. Morozova, N.I. Lyashenko // Metodi ta zasobi upravlinnya rozvitkom transportnikh sistem: Sb. nauk prats'. - 2008. - № 13. - Odesa: ONMU. - S. 5-19.

2. Kirillova, E.V. Organizatsiya $i$ upravlenie rabotoi sudov $v$ rolkernoi transportno-tekhnologicheskoi sisteme [Text]: dis. kand. tekhn. nauk: 05.22.01 / Kirillova Elena Viktorovna. - Odessa, 2005. $-229 s$.

3. Dorigo, M. The Ant System: Optimization by a colony of coopereting agents. IEEE Transactions on Systems, Man and Cybernetics [Text] / M. Dorigo, V. Maniezzo, A. Colorni. - Part B. -Vol. 26. - № 1. - 1996. - P. 1-13.

4. Krishnaiyer, K. Ant Algorithms [Text]: review and Future Applications / K. Krishnaiyer, S.H. Cheragh // IERC'02, Industrial Engineering Research Conference, Orlando, USA, may 2002.

5. Ritchey, T. Scenario Development and Risk Management using Morphological Field Analysis [Text] / T. Ritchey. Proceedings of the 5th European Conference on Information Systems (Cork: Cork Publishing Company). - Vol. 3. - P. 1053-1059.

6. Zwicky, F. Discovery, Invention, Research - Through the Morphological Approach [Text] / F. Zwicky, Toronto, 1969. - The Macmillan Company. $-187 p$.

7. Sychev, A.A. Organizatsiya raboty transportnogo uzla $v$ sostave transportnogo koridora [Tekst]: Dis. ... kand. tekhn. nauk / A.A. Sychev. - Rostov - na - Donu: RGUPS, 2009. - 167 s.

8. Rizzoli, A.E. A simulation tool for combined/rail/ road transport in intermodal terminals [Text] / A.E. Rizzoli, N. Fornara, L.M. Gambardella // Mathematics and Computers in Simulation. - 2002. Vol. 59. - Issues 1-3. - P. 57-71. DOI: 10.1016/s03784754(01)00393-7.

9. Beletskii, YU.V. Analiz sistemy vzaimodeistviya razlichnykh vidov transporta na osnove formirovaniya transportno-logisticheskikh tsepei pri mul'timodal'nykh perevozkakh [Text] / YU.V. Beletskii, N.V. Miroshnikova, A.V. Sergienko // Visnik Skhidnoukraïns'kogo natsional'nogo universitetu im. V. Dalya. - 2015.- № 1 (218). S. 210-219.

10. Brandimarte, P. Introduction to distribution logistics [Text] / P. Brandimarte, G. Zotteri. - J. Wiley \& Sons, Inc., NY, 2007. $587 \mathrm{p}$. 
ВІСНИК

ОДЕСЬКОГО НАЦІОНАЛЬНОГО

МОРСЬКОГО УНІВЕРСИТЕТУ

№ 1 (64), 2021
HERALD

OF THE ODESSA NATIONAL

MARITIME UNIVERSITY № 1 (64), 2021

11. Morozova, I.V. Dynamic Optimization Model for Planning of Integrated Logistical System Functioning [Text] / I.V. Morozova, M.Ya. Postan, S.N. Dashkovskiy // Lecture Notes in Logistics, 2014. - P. 291-300. DOI: 10.1007/978-3-642-35966-8-24.

12. Murad'yan, A.O. Metodika uzgodzhennya parametrivi optimizatsii protsesu perevalki vantazhiv $v$ zagal'notransportnikh vuzlakh [Text] / A.O. Murad'yan // Visnik Odes'kogo natsional'nogo mors'kogo universitetu: Zb. nauk. pr. - Odesa: ONMU, 2014. - Vip. 1 (40). - S. 127-135.

Стаття надійшла до редакиії 23.02.2021

Посилання на статтю: Мурад'ян А.О. Методика узгодженого управління підприємствами на базі транспортного вузла // Вісник Одеського національного морського університету: Зб. наук. праць, 2021. № 1 (64). С. 112-123. DOI 10.47049/ 2226-1893-2021-1-112-123.

Article received 23.02.2021

Reference a JournalArtic: Muradyan A.O. Methodology of harmonized management of enterprises on the basis of transport hub // Herald of the Odessa National Maritime University. 2021. 1(64), 112-123. DOI 10.47049/ 2226-1893-2021$1-112-123$. 